\title{
New Trade Leads the Transformation of Fostering Applied Undergraduate Talents in Cross-border E-commerce
}

\author{
Ming Luo \\ Institute of Finance and Economics \\ Guangdong University of Science and Technology \\ 523083 Dongguan, Guangdong, China \\ E-mail: luoming8654@163.com
}

\author{
Biaoxin Chen \\ Innovation and Entrepreneurship College \\ Guangdong University of Science and Technology \\ 523083 Dongguan, Guangdong, China \\ E-mail:394797228@qq.com
}

\begin{abstract}
With the arrival of the new trade era, the development of cross-border e-commerce enterprises in China brings great opportunities and challenges. Crossborder e-commerce applied undergraduate talent training, not only related to the operation of cross-border e-commerce enterprises, but also has an important impact on the overall development of cross-border e-commerce industry. Based on the opportunity and challenge of talent training of crossborder e-commerce in the new trade era, this paper briefly expounds the meaning and characteristics of cross-border ecommerce in the new trade era. Then discuss the direction of talent training under its background and the realization path of talent training is put forward. The purpose of this paper is to provide reference suggestions for the training and development of cross-border e-commerce talents in the new trade era and to promote the development of cross-border ecommerce industry.
\end{abstract}

Keywords: new trade; cross-border e-commerce; applied undergraduate; talent training

Under the new trading environment, the development of cross-border e-commerce enterprises has become more and more prosperous, and the export and training of personnel for them has gradually formed the problems to be considered in the future society. The cultivation of cross-border e-commerce talents can not only promote the circulation of domestic and foreign trade, but also have an important impact on the growth of our national economy. At present, China has more than 5,000 cross-border platform enterprises and more than 200,000 foreign trade enterprises carrying out cross-border electronic commerce through the platform According to the China Electronic Commerce Research Center (100EC.CN), China's overall cross-border e-commerce transactions scale in 2017, has reached CNY $¥ 7.6$ trillion according to monitoring data(Including retail and $\mathrm{B} 2 \mathrm{~B}$ ).

\section{IMPLICATIONS OF NEW TRADE}

New trade is related to traditional international trade. The traditional international trade, Yiwu market and the Canton Fair and so on become the discrete center, the new trade age relies on the platform powerful backup support and the intelligence, the convenience, the intensive cross- trade comprehensive service, make business opportunities fall into the real business performance quickly.

Over the past decade, cross-border electronic commerce has been based on the Internet and the flow of data has changed the traditional situation of obtaining, displaying and linking information in international trade. With the change of original paper contracts, documents and face-to-face communication to the trade form with virtual mode and changed the structure and ecosphere of global consumers, producers, suppliers and middlemen, and gave birth to the platform enterprises, such as DHgate, AliExpress, Ebay, Amazon and so on.

With the continuous deepening of the Internet revolution and the display of new forms of business, the trend of "New Retailing " is echoed in the domestic market. In the international market, it is evolving to a new stage of "New Trade ". CEO Shutong Wang, founder of DHgate, believes that "New Trade" is based on artificial intelligence, virtual reality, big data and other technologies as well as the deep integration of industry, transnational trade has become visible, audible, touchable, palpable and usable. Whether it is artificial intelligence commodity identification, AR intelligent customer service, virtual factory, or instant translation, in the new trade era, these scientific and technological means will be deeply integrated with our industry, enhancing the efficiency of cross-border trade greatly. In the new trade era, foreign trade can be as simple and efficient as domestic trade.

The new generation of information technology industry has become an important force in the transformation of new and old kinetic energy. The new generation of information technology forms such as Internet of things, Internet of things, cloud computing, big data, artificial intelligence, virtual reality technology, etc. And the global trading environment has changed dramatically. The whole international trade industry, the buyer and seller realized the information exchange on-line and realized the platform informationization from $\mathrm{B} 2 \mathrm{~B}$ yellow page transaction 1. 0 era in 1999. In 2004, DHgate started the 2.0 era of B2B online trading. The online order transaction between buyers and sellers, including electronic payment and order delivery logistics, other new services include: digital 
display of goods; online customer service management, etc. It accumulates a large number of transaction services data, the realization of online trading services. In the 3.0 era, DHgate, AliExpress and other platforms are constantly committed to create an integrated trading service platform. Transactional platform extends to the service platform online services to expand to marketing. Finance, warehousing and other mining big data brings value. For example, intelligent search recommendations, precision marketing, financial services and so on. The trade service line has been realized. With the formation of a new trade biosphere, related industries other than trading and trade services have been continuously integrated into platformcentric trade activities to provide more ancillary services, such as management, research and development, Financing and other enterprise-level services have opened up isolated information islands, enhanced data connectivity and analysis and promoted the industrial structure of cross-border trade.

\section{CHARACTERISTICS OF NEW TRADE}

In the new trading era, goods and services are visible, audible, touchable, palpable and usable, and foreign trade can be as simple and efficient as domestic trade. There are three main features of new trade:

\section{A. Technology Drive}

Science and technology are undoubtedly the original driving force of the new trading era. Big data, cloud computing, artificial intelligence, virtual reality and other technologies have laid the most important foundation for the new trading era. Technology has made the business of the new trading era more intelligent and convenient. In the new trading era, when artificial intelligence fell from the air to the ground and was deeply integrated with crossborder e-commerce, it was like putting wings on the ship and turning it into a spaceship, a fusion that has been, and will be, done more on cross-border platforms. Technology such as Digitalization, Intelligentization, Gridding, Big data, Cloud computing and Blockchain will be more and more intelligent and lightless. For example, the similar recommendation function on mobile network of DHgate mobile network will help the platform GMV (Gross Merchandise Volume) increase more than $20 \%$.

\section{B. Service Integration}

Marketing training, warehousing logistics, customs and tax collection, payment amount, etc., will continue to be intelligent, intensive, platform, the value of the platform will no longer be limited to the flow, "serve, on the platform" will become a habit. For example, logistics, the cargo has to be sent to more than 100, 000 cities and ports in more than 200 countries around the world, planes, trains, ships, and other means of transport combine thousands of routes, including packing boxes, customs clearance, foreign transportation, and so on. The combination of complex different linear equations, cost-effective the best choice of the answer, even if given to the professional companies also often need to face a large number of service providers, spend a lot of manpower and material resources. The intelligent logistics system in the new trade era, the platform will use big data algorithm according to the specific circumstances of each single, in a large number of logistics routes for you to match the best intelligent solution, and by the special team door, Provide receiving, packing, customs clearance, transportation of a complete one-stop service. All you have to do is focus on the product, prepare the product, move your fingertips, and give everything you have left to the platform.

\section{Fusion Unbounded}

Unlike cross-border e-commerce, new trade focuses more on online integration of resources and must be a combination of online and offline, globalization and localization. For example, the digital trading center of DHgate Digital Trade Center, DTC for short, Several DTCs have been set up in seven countries around the world, covering more than 100 million potential consumer customers, matched by smaller, more flexible franchises with peripheral radiation, a business model of "DTC + one net million stores" that combines online and offline, integration of pre-sale, in-sale, after-sales, full-process services can help suppliers to provide overseas buyers with sample experience, ordering, on-site delivery and return and exchange of goods and other integrated services. Although all are to shop, APP orders, rapid delivery, but the DTC will browse the goods, sample experience, return and exchange, logistics control and other links to the landing abroad. Need to expand global localization and online and offline integration to overseas markets and global replication, is clearly more complex than it is at home.

\section{Cross-BORDER ElECTRONIC COMMERCE COURSE AND TRAINING OF NEW TRADE TALENTS}

In the process of training new trade talents, the teaching should be involved in more cross fields of knowledge, and have certain difficulty and depth, close to the needs of the new trade talents with high comprehensive quality in the information society. The actual implementation of the process of curriculum and teaching methods have certain requirements, curriculum should be cross-cutting, involving a wide range of technical and teaching methods should have a good scientific, deliberative and exploratory. Business intelligence is one of the courses to carry out the training conditions of new trade talents. It is a cross-cutting subject that integrates management science, information technology, data statistics and artificial intelligence. It involves a wide range of knowledge. To help learners to learn the core technologies of data warehouse, data mining, report analysis and data statistics and lay a solid 
foundation for students to go to large cross-border ecommerce enterprises in the future. The actual teaching needs to take the actual demand of cross-border ecommerce enterprises for new trade talents as the starting point, to take the ability expectation of cross-border electronic commerce enterprises to the new trade talents as the guidance and to promote the teaching by the new teaching method. Promoting teaching by combining theory with practice and learning from relevant experience of foreign business intelligence course, innovating in teaching material construction, teaching content and teaching method. Its purpose to cultivate both solid professional knowledge and skills foundation, and to master the knowledge of many cross-disciplinary, and has a good analytical ability and practical application of talent. The specific implementation methods are as follows.

\section{A. Make Good Use of the "Light Assets" Model}

On the basis of maintaining the existing advantages and characteristics, the traditional international trade and e-commerce majors have gradually transformed into innovative cross-border e-commerce professionals training direction based on the new trade. In the new trade era, the application of big data and other technologies will eliminate the traditional trade pattern of obtaining benefits by asymmetric information, and the flow of information will become more transparent and efficient. This requires sellers to build closer "partnerships" with customers that go beyond price benefits. In addition to differentiated, cost-effective products, good experiences, services, and quick, timely feedback are also becoming increasingly important in the new trading era, and quires participants to be able to lead services around the world. To realize the localization of storage, display, after-sale, logistics and other services. The transformation of international trade courses takes place in three steps, with a complete transformation in two or three years. The first step is to introduce course on cross-border electronic commerce and to develop teaching materials on cross-border electronic commerce. There are mainly cross-border e-commerce platform rules, cross-border electronic commerce products, data analysis and drainage, visual design and cross-border logistics and so on. The second step is to set up courses such as mobile e-commerce technology, mobile APP development, mobile marketing planning, mobile entrepreneurship and so on and carry out the construction of mobile Internet laboratory. The third step is to introduce new trade-related courses such as artificial intelligence, virtual reality, big data and "DTC + one net shop" to complete the transform new trade.

Referring to the latest teaching methods at home and abroad, aiming at training new trade talents to meet the actual needs of cross-border e-commerce enterprises, the traditional "spoon-feeding" passive teaching and learning is transformed into research-oriented, collaborative and case-based learning. The teacher is transformed from a simple teacher to a guide and a consultant, who is responsible for providing students with the appropriate depth and difficulty of the research topics, to guide the students' learning. And scientific design of practical courses according to the ability needs of cross-border ecommerce enterprises [4].The design of the teaching content refers to the "reverse engineering" style of the famous foreign universities is to understand the real demand for the knowledge and the ability of the famous cross-border e-commerce enterprises to acquire the new trade talents. Prepare to grasp the depth and difficulty of the core knowledge in business intelligence, such as data warehouse, data mining, report analysis, etc., extract the knowledge points closely related to the course and then form a teaching plan. According to the intersection of knowledge in other fields, the course content is improved scientifically and systematically, and then the perfect curriculum content is designed. This kind of "reverse engineering" teaching content design can optimize the traditional teaching content. Keep up with the development trend of the new trade industry, close to the actual needs of enterprises, so that the talents can truly meet the enterprises needs for comprehensive talent. As an intersecting course which can play an exploratory role in the training of new trade talents, the horizontal domain knowledge of business intelligence involves a lot, which can broaden the knowledge of learners. Enable them to systematically and effectively master the basic knowledge of information management, data analysis, management strategies, and the depth of professional content and practical courses can help strengthen students' ability to develop relevant technologies and applications of business intelligence, make it stand out in the fierce talent market. In this way, the limitation of single curriculum knowledge can be broken and the domain knowledge related to business intelligence curriculum can be integrated into an organic knowledge network on the basis of clarifying the relevant contents of each course [5].

\section{B. Focus on Innovative Teaching Methods of Core Business}

International trade involves institutional constraints such as customs clearance, taxation, foreign exchange settlement and more complex business environments such as transnational logistics. In the new trading environment, enterprises must consider how to maximize the simplification of management processes. This requires challenging their traditional thinking patterns, abandoning non-core functions, finding the right partners in the ecosystem and learning from each other in non-core areas such as customs, logistics, payments, finance, etc. Focus energy and resources on creating high-value businesses. Combined with deliberative teaching, the cultivation mechanism can be realized in many aspects. In business intelligence course teaching process, first of all, let the students know the future development direction and the 
ability of the new trade talents to stimulate the students' interest in learning business intelligence course. We can also introduce advanced foreign teaching methods such as "BTEC teaching method", "four-step teaching method", "PBL teaching method" and "iterative teaching method". According to the relevant needs of the real case simulation in cross-border e-commerce enterprises, designing practical projects with moderate difficulty and strong practicality can help students make good use of their knowledge of software engineering, data analysis, program development, etc. To improve their ability to think and solve problems independently, to enable them to learn new knowledge quickly and to apply it in practice, to use the relevant tools of business intelligence to complete small business intelligence projects and help them master the theoretical knowledge and professional skills that new trade talents need. The project is carried out in small groups to improve the project management and team coordination skills of the participants. In this process, teachers play a leading role, managers, supervisors, responsible for the curriculum learners to provide reference advice and appropriate help.

\section{Embracing the Strong Platform and Constructing the Cooperative Education Base}

Strengthen cooperation with cross-border e-commerce platform enterprises to provide learners with more practical case analysis capabilities as well as some free software tool. Integrate enterprises' actual needs of new trade talents and the specific objectives of talent training according to the requirements of employment posts design teaching methods, emphasizing the application of teaching mode. Large cross-border e-commerce platforms, such as DHgate, AliExpress, Amazon and ebay, are leading crossindustry representatives and should establish close cooperative relationships with these well-known crossborder e-commerce companies. And carry out a variety of forms of cooperation on this basis, promote the combination of business intelligence teaching and industrial interaction and further promote the business intelligence field of new trade talent training results. In addition, senior researchers from relevant enterprises can also be hired to give cutting-edge lectures for new trade learners so that they can gain a better understanding of the actual needs of the market for talents in the new trade field, so that they can have a more targeted knowledge and skills reserve. And provide some practical software tools and practical new trade cases to use, so that the students have the initial practical ability of the new trade-related technology to achieve the docking of learning and work in the school. In the new trade era, great changes have taken place in the way of organization and agglomeration of trade activities. The powerful internet platform is gradually changing from a flow and trading platform to a comprehensive service platform. It is a gathering center for information acquisition, display and negotiation, which expands and integrates the processes of marketing, logistics, payment, etc. Evolving to a converging business flow, logistics, information flow, capital flow and people flow key path.

\section{ACKNOWLEDGMENT}

(1) Higher Education Reform Project of undergraduate Colleges and Universities in Guangdong Province [2016] 236. (569)

(2) 2015 Higher education innovation strong school project in Guangdong University of Science and Technology [2016] 18 (2)

\section{REFERENCES}

[1] Shutong Wang. Cross-border E-commerce is becoming into the second half, the new trading era is coming.[OL] http://seller.dhgate.com/industry-trends/c_41131.html. 2018-03-19

[2] Jack Ma The electronic commerce will disappear, "five new" will subvert traditional industries[J]. Informatization Construction, 2016(11):18-21.

[3]. Bosch forms new regional business unit - Filtration Americas[J]. Filtration Industry Analyst, 2008, 2008 (9).

[4] Yu-Hsiang Hsiao,Mu-Chen Chen,Wei-Chien Liao. Logistics service design for cross-border E-commerce using Kansei engineering with text-mining-based online content analysis [J]. Telematics and Informatics, 2016.

[5] Ziliang Deng,Zeyu Wang. Early-mover advantages at cross-border business-to-business e-commerce portals [J]. Journal of Business Research,2016,69(12). 